\title{
Habitat and Behavioral Observation of Indian Flying Fox Pteropus giganteus (BRÜNNICH, 1782) in Sallaghari, Bhaktapur, Nepal
}

\author{
Jamuna Prajapati $^{1}, \bigotimes$ Mukesh Kumar Chalise ${ }^{2}$, and Dikpal Krishna Karmacharya ${ }^{3}$ \\ 1Bhaktapur Multiple Campus, Bhaktapur; 2Central Department of Zoology, \\ Tribhuvan University, Kirtipur, Kathmandu, Nepal; 3Global Primate Network Nepal \\ GPO Box 26288, Kathmandu, Nepal; \\ prajapatijamuna51@gmail.com
}

\begin{abstract}
The study on Indian flying fox (Pteropus giganteus), the most diverse group of mammals, was conducted from17th September, 2016 to 3rd March, 2017 at Sallaghari, Bhaktapur to collect baseline information on habitat, behavior, population and threats. The population structure and estimated populations along with their habitat using direct observation and the branch estimation method were assessed. The general behaviour of the individual animal was observed and recorded using focal animal sampling over a 10 minute periods either in the morning or evening. Local people and members of the Nepal Army were interviewed using semi-structured questionnaires in order to assess threats. Most flyng fox were found roosting in tall Eucalyptus spp. trees and the highly branched Populus spp. Resting was observed as the most the dominant behavior among male, female and young individuals during the study period. Highest populations $(\mathrm{n}=1421)$ were observed in September 2016 and lowest $(n=36)$ in February 2017. Habitat destruction, lack of food, urbanization and electrocution were the major threats to $P$. $g i$ ganteus. The population is decreasing compared to previous studies. Electrocution and persecution by humans are the major causes of accidental death each year. Therefore, in order to conserve and save this species, habitat and afforestation along with awareness programs should be implemented urgently.
\end{abstract}

Keywords: Chiroptera, Bats Monitoring, Pollinators, Threats, Conservation 


\section{INTRODUCTION}

Indian flying fox (Pteropus giganteus), is considered as one of the largest bats and is widely distributed in the Indian subcontinent (Kryštufek, 2005) and widely distributed from Bangladesh, Bhutan, India, Maldives, Nepal, and Pakistan to Sri Lanka (Molur et al., 2002)

recorded from sea level to an elevation of 2,000 $\mathrm{m}$ above sea level (Smith and Xie, 2008). It is listed as 'Least Concern' in International Union for Conservation of Nature (IUCN) Red List of Threatened Species (IUCN, 2017) and appendix-II in Convention on International Trade in Endangered Species of Wild Fauna and Flora (CITES, 2017).

As a social species Pteropus giganteus lives in a large diurnal roost which comprises several hundreds or even thousands of individuals usually located in well exposed trees such as Ficus bengalensis, F. religiosa, Tamarindus indicus, Mangifera indica, Dalbergia sissoo and Eucalyptus spp. (Mathur et al., 2012). The colony size varies according to food availability in its nightly foraging habitat (Williams et al., 2006), roosting preference observed in thick foliage for sun or rain protection (Vardon et al., 2001). It swallows soft fruits or juice extract spitting out the remains known as bolus, containing the residual fruit pulp of fibrous fruits, seeds. Further, also known to feed on juice and pollen of various tree flowers (Chakravarthy et al., 2008), plays a key role in forest regeneration because of its ability to retain viable seeds in gut for several hours (Shilton et al., 1999). Their long-distance foraging movements (Tidemann \& Nelson, 2004; Epstein et al., 2009) play important role in pollination of flower and dispersal of seed (Nyhagen et al., 2005).

Its population was about double just five years back in Sallaghari, Bhaktapur (Raichal, 2006). However, threats for the survival of $P$. giganteus included netting, shooting for meat, habitat destruction, cutting down of roost trees, urbanization, development projects and loss of wild fruits (Rajchal, 2007; Reginald et al., 2008; Chakravarthy \& Yeshwanth, 2008). Since, there is a lack of current data and status of this species in the area, this study aims to provide the updated information on the population, behaviour, habitat and existing survival threats in Sallaghari, Bhaktapur, Nepal along with the objectives of determination of its habitat and roosting sites, exploration and description of general behavior, estimation of population size and assessment of its major survival threats in Sallaghari, Bhaktapur, Nepal. 


\section{Study Area}

The study area Sallaghari (fig. 1) is the west fringe of Bhaktapur Municipality whichcovers region between $\mathrm{N} 27^{\circ} 36^{\prime}-27^{\circ} 44^{\prime}$ and $\mathrm{E} 85^{\circ} 21^{\prime}-85^{\circ} 32^{\prime}$ and $13 \mathrm{~km}$ away from capital city Kathmandu. The altitude ranges from $1,331 \mathrm{~m}$ to $2,191 \mathrm{~m}$ above sea level with the highest peak of the district lies at Nagarkot (DDCO, 2017). The study site is surrounded by river, streams, ponds as well as cultivated farm lands. The study site is located in and around the compound of Sainik Aawasiya Mahavidhyalaya of Sallaghari, Bhaktapur.

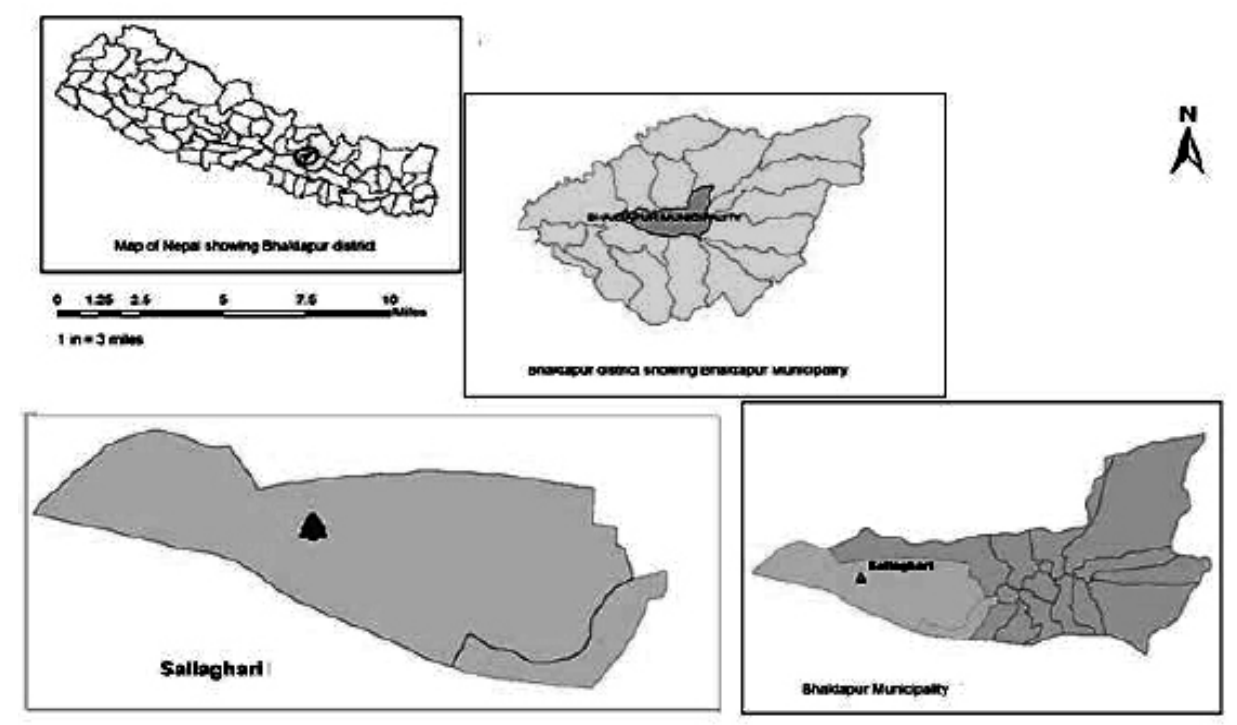

Fig. 1. Map of Sallaghari, Bhaktapur District.

\section{MATERIALS AND METHODS}

\section{Direct field observation}

Direct field observations were done to monitor the population and behaviour of the study species. Floral and faunal diversity were monitored for the habitat assessment. The field site was visited from September, 2016 to March, 2017 once a week covering early spring and winter which are the peak and scare seasons respectively for the bats (Koju \& Chalise, 2010; Manandhar, 2015). A total of 144 hours of survey and monitoring efforts were applied averaging three hours a day for six months. Bushnell $850 \mathrm{R}$ range finder was used to measure the height of the roosting trees and height of the 
roost above the ground on the tree branches. A computerized program (Google earth) was used for exploration of the roosting sites from the nearest human settlements, road, agricultural land, water sources and picnic spots. Geographical location and elevation of the roosting sites were recorded with Global Positioning System (GPS) for navigation. Diameters at breast height $(\mathrm{DBH})$ of the roosting trees were measured using measuring tape.

\section{Focal animal sampling}

Focal animal sampling method (Altmann, 1974) was followed to record the general behaviour of the individual animal in each roosting sites. To get proper informationon behaviour of bat, different age/sex group of the animals were selected from the roosting groups. Theywere categorizedinto male, female and young. Celestron ultima 60x80mm spotting scope and the Bushnell 10x42 mm binocular were used to observe the behaviour of the animal. Each individual was observed for 10 minutes taking their behavioural data andthe process was repeated for 2-3 hours. The general behaviour of 43 males, 21 females and 13 young animals were observed and recorded in the morning and evening. Fourteen characters (grooming, crawling, resting, flapping, swinging, mating, excreting, yawning, flight, fighting, foraging, and spreading wing, covering body from wing, chattering)were observed during roosting time.

\section{Branch estimate method}

The branch estimate method was applied to estimate the total population of bats (CCINSA \& CSGSA, 2006) in the study area. For evaluating the changes in population of bats with season, Chi square $\left(\chi^{2}\right)$ test was carried out to determine the significant difference between the flock size in the winter and autumn season.

\section{Semi structured questionnaire survey}

Semi-structured interviews were used to investigate the locals' and visitors' perceptions about the status and the threats of flying fox in the area. The interviews were taken with 20 local people and members of Nepal Army during the field period. The interviews were conducted in Nepali language, and the interviews typically lasted between 20 minutes. The interviews were taken one by one to assure independence of the data (Lammertink et al., 2003). 


\section{RESULTS AND DISCUSSION}

\section{Habitat assessment}

By employing a computerised program (google earth) it was found that the nearest distance of the roosting trees from the road, human settlement, and agricultural land was $7.39 \mathrm{~m}, 10.37 \mathrm{~m}$ and $41.1 \mathrm{~m}$ respectively. The nearest pond Rani Pokhari was $35.5 \mathrm{~m}$ away from roosting trees whereas Siddhapokhari was about $569.42 \mathrm{~m}$ away where we found two dead bats hanging down on the electric wires. The distance from the roosting trees to the nearest stream and picnic spot were $224.89 \mathrm{~m}$ and $313.78 \mathrm{~m}$ respectively.

The flying foxes were observed roosted on Eucalyptus (Eucalyptus spp.) followed by Lahare Peepal (Populus spp.) and Khari (Celtis australis). Twenty-eight Eucalyptus trees, 12 Lahare Peepal, three Khari, and two of each Kaiyo and Siris were recorded as roosting trees in the study area. The highest count was 1,421. Among them 58\% of the flying foxes were found to be roosted on Eucalyptus, 32\% on Lahare Peepal, $5 \%$ on Khari, $3 \%$ on Siris and only $2 \%$ on Kaiyo tree (fig. 2). Eucalyptus tree had the maximum $\mathrm{DBH}$ as $2.7 \mathrm{~m}$. The maximum height estimated of the roosting trees (Eucalyptus and Populus) were $39 \mathrm{~m}$ each having 58 and 63 roosted bats on them. Whereas shortest trees (Eucalyptus and Populus) were of $6 \mathrm{~m}$ each having 49 and 25 individuals roosted on them.

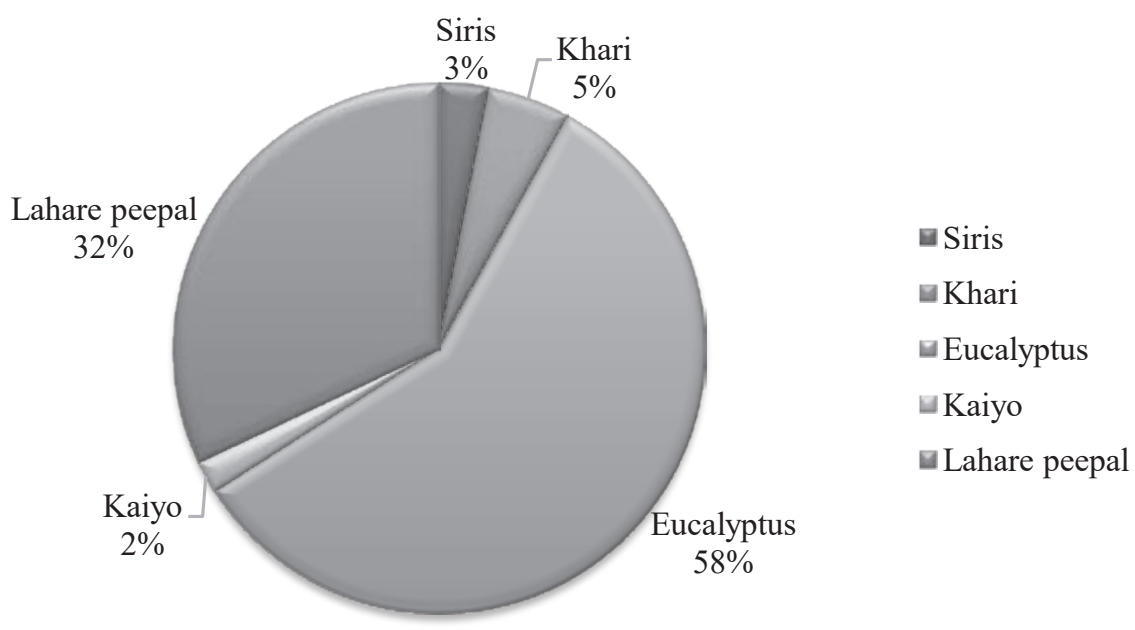

FIG. 2. Roosting trees of flying fox in Sallaghari, Bhaktapur. 
In present study, Eucalyptus was found to be favourite roosting tree of flying fox. It might be due to reason that the Eucalyptus tree is highly branched and taller than other trees in that area which provide more exposure to sunlight for warming the body. On the other hand, Kaiyo (Grevillea robusta) found to be the less favourable tree in the study site. The maximum DBH was found as $2.7 \mathrm{~m}$ that of Eucalyptus showing that the flying fox prefers roosting trees having greater DBH might be due to highly branched trees provides more place to roost. The nearest distance from the roosting tree to the road and human settlement shows that the road and human settlement has no effect on their roosting sites. The nearest distance from the roosting sites to the water source indicates they prefer to roost near the water source.

\section{Behaviour}

Fourteen different behaviours were categorized as recorded from the roosting sites from male, female and young individuals. The behaviour of male flying foxes was recorded for 430 minutes in 20 days. The resting was the dominant behaviour (31.5\%) whereas the excretion was the recessive behaviour (1\%) performed by male during the survey period (fig. 3). Most of the males were found aggressive than the females. They feebly prefer eating during the day time as they are the nocturnal creatures.

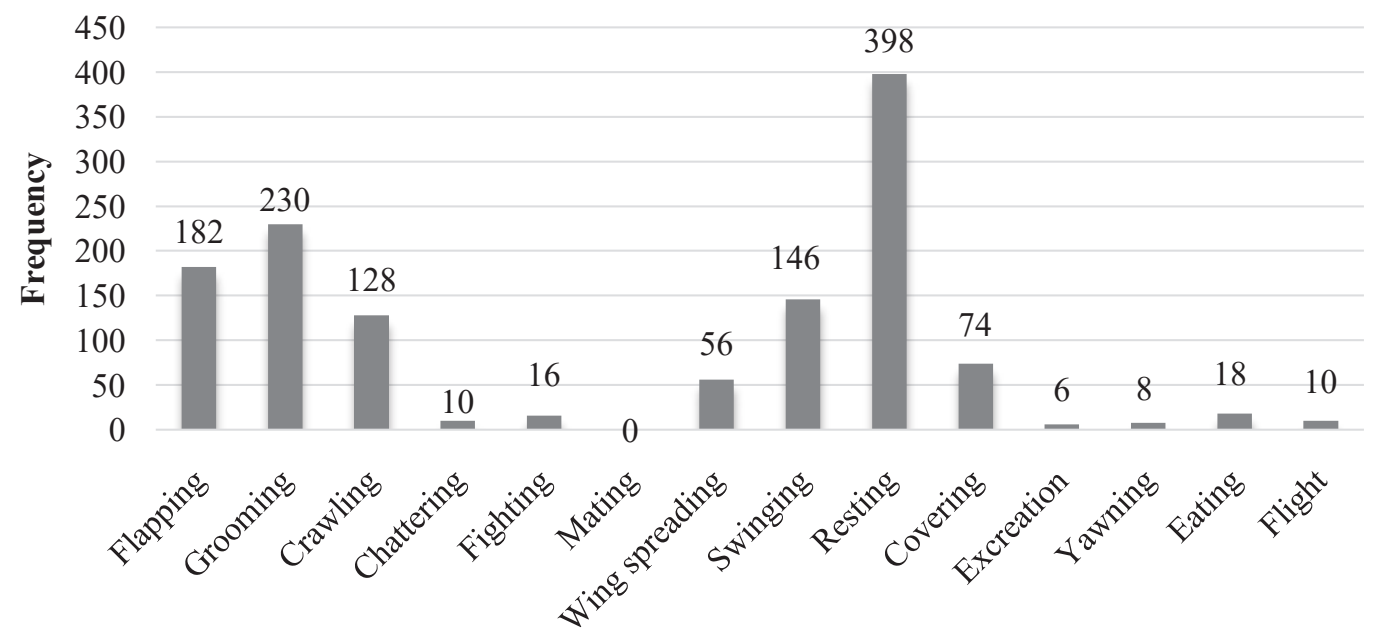

Types of behaviour 
The behaviours of females were recorded for 210 minutes in 20 days. The maximum behaviour $(34.92 \%)$ was resting whereas the minimum behaviour $(0.32 \%)$ performed by female was flight during the study period (fig. 4).

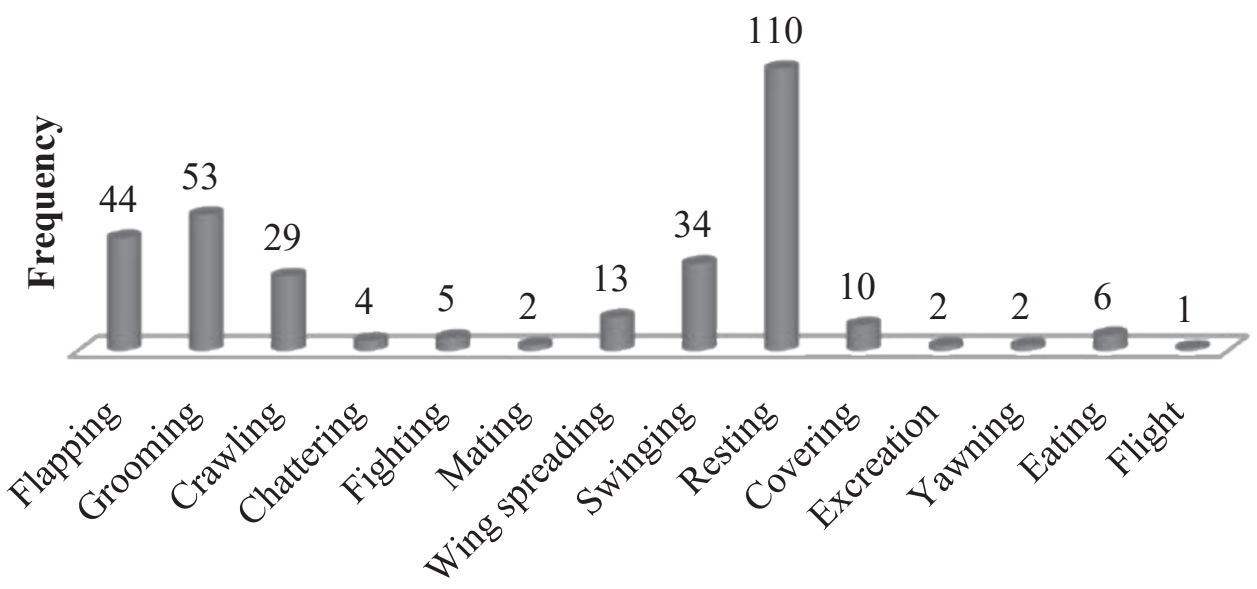

Types of behaviour

\section{Fig. 4. Behaviour of female flying fox in Sallaghari, Bhaktapur.}

The behaviour of young bats were recorded for 130 minutes for 20 days. The maximum behaviour (36.76\%) was resting whereas the minimum behaviour (1.62\%) performed by young individuals was chattering during the study period (fig. 5).

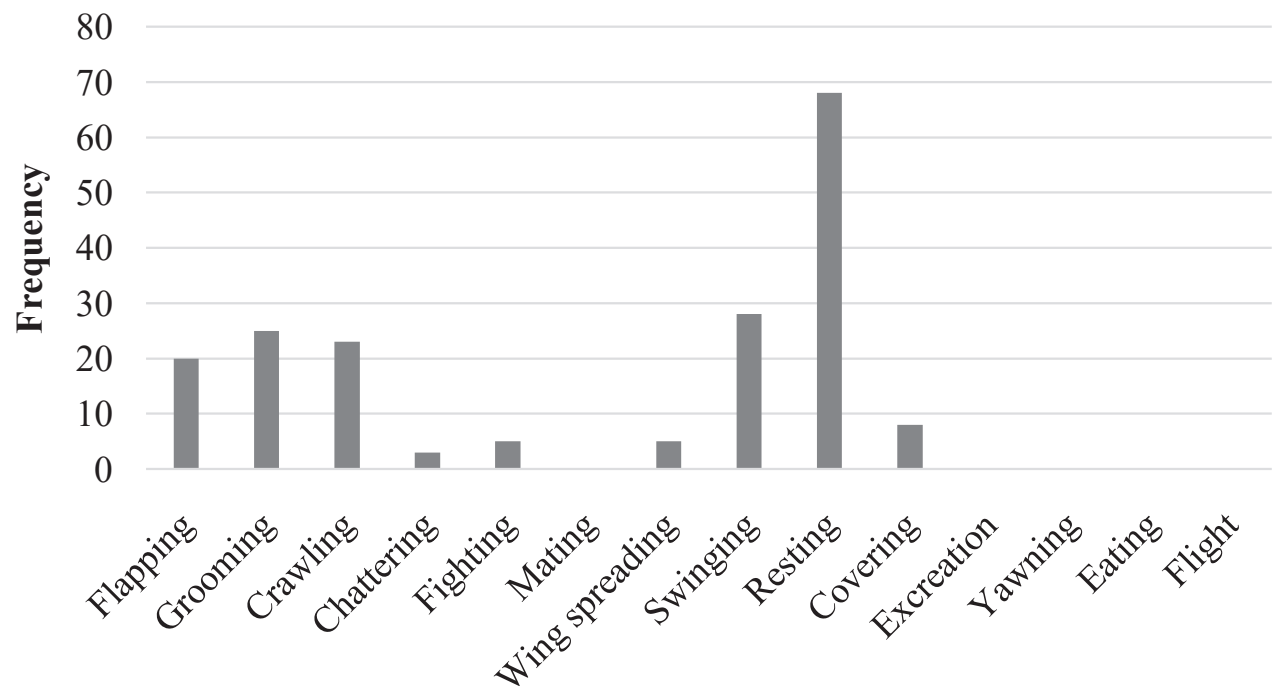

Types of behaviour 


\section{Fig. 5. Behaviour of young flying fox in Sallaghari, Bhaktapur.}

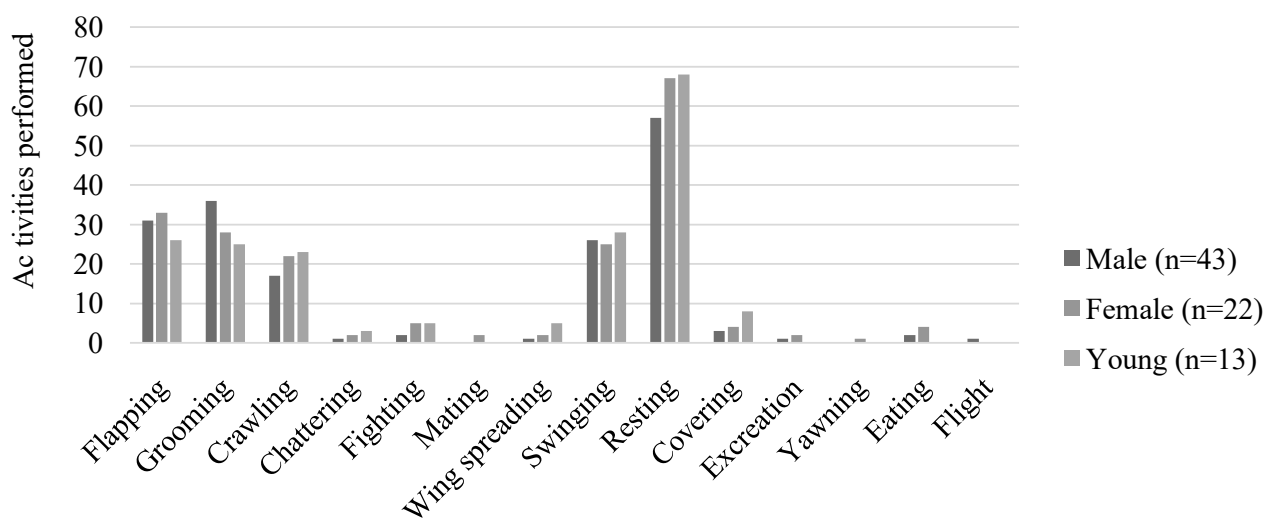

Behaviour of flying fox

Fig. 6. Comparative behaviour of male, female and young flying foxes during in Sallaghari, Bhaktapur.

At Sallaghari, September was found most favorable for the presence of flying fox whereas the unfavourable month was found to be February. The behavioural data indicates that the most preferred behavior for male, female and young is to rest. The highly preferred behavior shows that the resting in day time is due to the active participation at night for foraging or for other works as they are nocturnal. At the day time they showed less excretion indicating fewer metabolisms during resting.

\section{Population}

There were two roosting sites in the study area. One was near Rani pokhari and another was beside the road near the gate of Sainik Awasiya Mahavidhyalaya, Bhaktapur. The Maximum population was 1,421 on September 2016 whereas the minimum population was 36 on February (fig. 7). Among them the highest numbers of bats were counted in the morning as compared in the evening. The calculated chi square value was found to be 4067.849 which was greater than tabulated (30.144) at $\mathrm{df}=19$ in $5 \%$ level of significance. The flock size of flying foxes during the winter and autumn seasons $(\chi 2=4067.849, \mathrm{df}=19, \mathrm{p}=0.05)$ was differed significantly. 


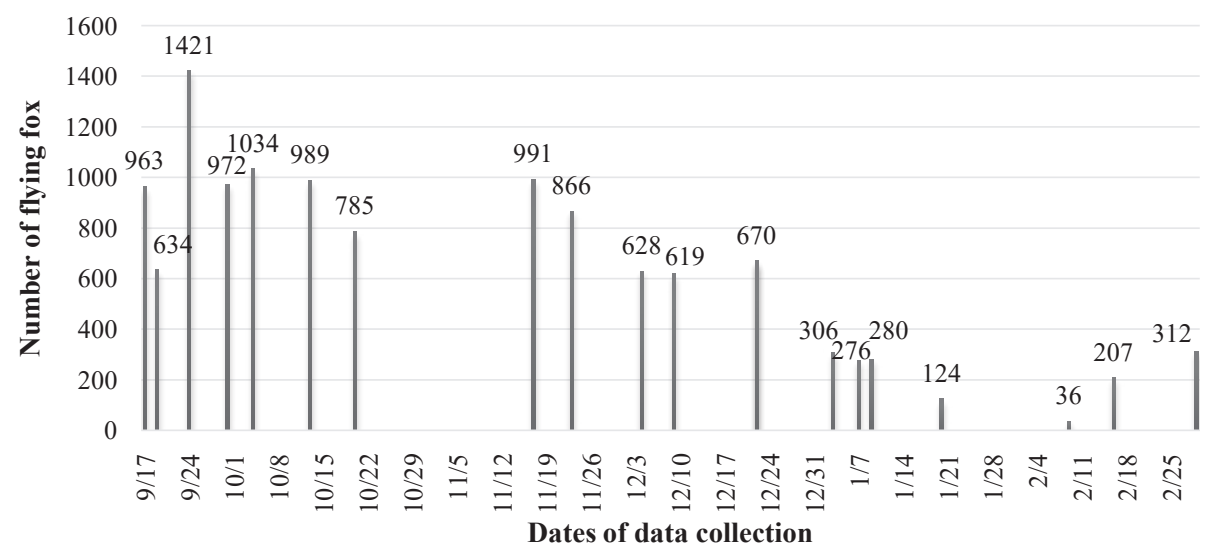

Fig. 7. Population fluctuations of flying fox in Sallaghari, Bhaktapur.

Maximum population was recorded in September and minimum in February. So it reveals that the population was higher in the spring season in the month of September, October and November. The spring season was more favorable for them than other season. As they are frugivorous, they would find more fresh fruits in the spring season. During data collection maximum number of population was recorded in the morning than in evening as they just returned after foraging.

\section{Threats}

Total 20 local people including army securities of the study area were selected for the interview. Among 20 respondents, 30\% agreed with deforestation as the major threats to bat, $20 \%$ agreed with pollution, $20 \%$ agreed with urbanization, $15 \%$ agreed with electrocution, and 15\% agreed with over population of human (fig. 8). Two dead individuals were found hanging down on the electric wires due to electrocution.

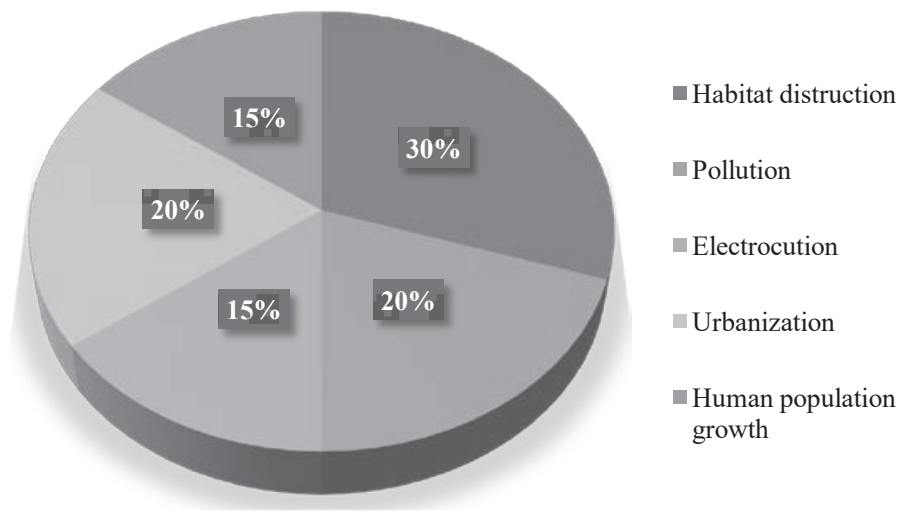




\section{Fig. 8. Responses of surrounding respondents on threats to flying fox in Sallaghari, Bhaktapur.}

Superstitious belief and misconception of the local people to the flying fox, these species are under the negligence of local people despite these are the friends of farmer. The lacking of the roosting trees due to habitat destruction and electrocution are the major threats to the bats of Sallaghari, Bhaktapur.

Sallaghari is considered as one of the best habitat for bats in Bhaktapur (Koju, 2008). Study area has Ranipokhari (pond) inside and traversed road to core city (Koju and Chalise, 2010). Sallaghari is also not far from human habitat. Animals live near human resident areas to remain secure from larger carnivores and also to obtain food easily (Chalise, 2003).

The present study showed that $P$. giganteus were found only on five tree species. The numbers of roosting tree are decreasing due to the deforestation and construction of building in the study area. The nearest distance from the roosting trees to the road and human settlements show that the current road and human settlements have no effect on their roosting sites. The nearest distance from the roosting sites to the water source indicates they prefer to roost near the water source. In previous studies, Pteropus population was recorded roosting in multiple tree species (Chakravarthy \& Yeshwanth, 2008; Bhatnagar \& Salvi, 2011; Senthilkumar \& Marimuthu, 2012; Dey et al., 2013; Timalsina \& Ghimire, 2010). Koju \& Chalise (2010) found that $P$. giganteus roosted in six species of trees in Sallaghari, Bhaktapur in which three were new tree species than earlier i.e. Persea spp., Lindera spp. and G. robusta. They roosted in five species of trees around Kesharmahal (Timalsina \& Ghimire, 2010; Koju \& Chalise, 2010). Similarly, P. giganteus were found to be roosted in seven tree species in Sallaghari (Manandhar, 2015).

Koju \& Chalise (2010) recorded P. giganteus roosting in Mulberry (Morusalba), Lahare Peepal (Populus spp.), Camphor (Cinnamomum camphora), Khari (Celtis australis), Chir Pine (Pinus roxburghii) and Eucalyptus (Eucalyptus species) in Sallaghari, Bhaktapur. Manandhar (2015) recorded Chir Pine (P. roxburghii) as dominant species and Eucalyptus as the major roosting tree in Sallaghari. The present study showed that large population of $P$. giganteus observed to be roosted in Eucalyptus spp. in Sallaghari and pollen and nectar of Eucalyptus blossoms as their favorable food. Also, maximum number of individuals found in Eucalyptus may be because of more trees of this species. 
According to this study, flying foxes were found spending most of the day time for rest and sleeping. Koju \& Chalise (2010) observed that $P$. giganteus spent more time in rest, groom, flap and wing spread among which the highest rank activity was resting in midday. Sleeping behaviour was the most frequent ( $>50 \%$ ) followed by groom, wing spread and wing flap. Besides these, movement in tree, nursing, mate, fight and flight were less frequent behaviours ( $<5 \%$ ) in Sallaghari and Keshar Mahal (Manandhar, 2015).

Population of $P$. giganteus was 1,428 found in September 2006 (Koju \& Chalise, 2010), 1,324 in November 2006 (Acharya, 2008) and 1, 550 in October 2014 (Manandhar, 2015) whereas during this study, population was 1,421 in September 2016. It reveals that the population of the flying foxes increase in September and October may be due to the favorable weather, temperature and presence of flowers and nectar rich fruiting trees like G. robusta (Manandhar, 2015) resembling this study. Koju \& Chalise (2010) found no flying foxes in January 2006. Manandhar (2015) found 264 in January but during the present study, 36 individuals were observed in February 2016. This minimum number might be due to unavailability of food in this season and might be they migrate to low land in search of food. The higher number in the morning than in the evening was also recorded as they returned from foraging in the early morning while started to fly with the approaching dusk.

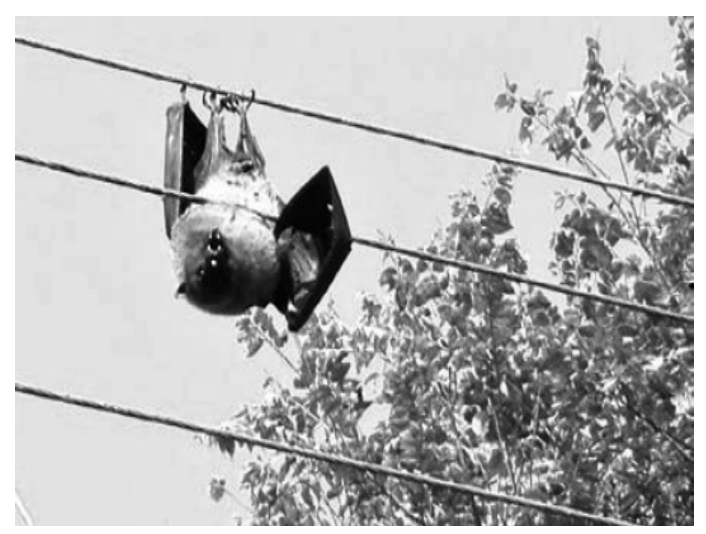

PLATE 1. Dead bat hanging down on electric wire nearSiddhapokhari
There are many threats to flying foxes.

One of the threats is Nepalese people commonly treat them as ghosts, witches, disease transmitters and dangerous animals and blame them for the cutting of soft horns and ears of domestic animals like cow, buffalo and goat (Thapa et al., 2012). Chepang people kill the flying fox during the flowering of the Butter tree (Diploknena butyracea) also called Chiuri in Nepali language and serve as the source

of meat (Limbu \& Thapa, 2011). According to Thapa et al., (2012), Newar community of Kathmandu valley used to kill flying fox to make bat oil that was used as medicine or as ear-drops to expel an ear bug, as a topical baldness cure and as an 
anti-paralytic. In addition, electrocution is also one of the major threats prevailing in Sallaghari (Rajchal, 2006). More than ten dead flying foxes are found every year due to electric shock and was the highest threat in the locality. Only one household consumed the fallen flying foxes for food and medicine (Manandhar, 2015). We also found two bats died due to electric shock during our field period (Plate 1). Therefore, besides medical use electrocution is the major cause of their number decline.

Habitat alteration and the environmental factors also have a devastating effect on tree-roosting populations (O'Brien, 2011). Therefore, the present study reveals that Sallaghari is almost inside the urban vicinity. Human disturbances and unprotected electric wires are the major threats of the flying fox population in Sallaghari. Hence, proper management of their habitat for the conservation is urgently needed. Regular monitoring on the status of $P$. giganteus should be continued in Sallaghari. The area should be announced as flying fox conservation area so that further researches, taxonomical study, plantation of fruit trees, and community outreach programs can be carried out to make people aware and to protect the species from local extinction. Electrocution and persecution by humans are the major causes of accidental death every year. So, in order to conserve and save this species, afforestation work, along with an awareness program in surrounding should be started.

\section{ACKNOWLEDGEMENTS}

We would like to express our deep gratitude to Neeru Dhakal for her continuous support.We are indebted to Kritan Raya, Sandhya Manandhar, Shreejana Awal, Milan Tamakhu and all the friends and staffs of Bhaktapur Multiple Campus for their continuous encouragements. We appreciate help from Sainik Awasiya Mahavidhyalaya for their kind support and friendly behaviour during thefield work. We would like to thank Dr. Dayaram Bhusal and Ganga Ram Regmi for reviewing and providing critical commentson the manuscript. 


\section{REFRENCES}

ACHARYA, P. R (2008) Status and distribution of Indian Flying Fox in Kathmandu Valley, Nepal. Bat Net - CCINSA Newsletter, 9, 19-20.

ALTMANN, J (1974) Observational Study of Behaviour: Sampling Methods. Behaviour49(3,4): 227-267.

BHATNAGAR, C; SALVI, R (2011) Sites and Roosting Ecology of Bats of Udaipur District, Rajasthan. Small Mammal Mail - Bi-Annual Newsletter of CCINSA \& RISCINSA 3: 31-35.

CCINSA; CSGSA (2006). Project Ptero Count. Bat Net Newsletter 7: 9-11.

CHAKRAVARTHY, A K; YESHWANTH, H M (2008) Status of Roost of Indian Flying Fox (Pteropus giganteus Brunnich) in Karnataka, South India. Bat Net CCINSA Newsletter 9: 16-18.

CHALISE, MK (2003) Assamese monkeys (Macaca assamensis) in Nepal. Primate Conservation 19: 99-107.

CITES (2017) Convention on International Trade in Endangered Species of Wild Fauna and Flora. Appendices I, II and III (https://cites.org/sites/default/files/ eng/app/2017/E-Appendices-2017-04-04.pdf).

DDCO, (2017) Bhaktapur District Development Committee Office, http://ddcbhaktapur. gov.np/en/brief-introduction/downloaded on 18th May, 2017.

DEY, S; ROY, U S; CHATTOPADHYAY, S (2013). Distribution and Abundance of Three Populations of Indian flying fox (Pteropus giganteus) from Purulia District of West Bengal, India. TAPROBANICA: The Journal of Asian Biodiversity 5(1): 60-66.

EPSTEIN, J H; OLIVAL, K J; PULLIAM, J; SMITH, C; WESTRUM, J; HUGHES, T; DOBSON, A P; ZUBAID, A; RAHMAN, S A; BASIR, M M; FIELD, H E (2009) Pteropus vampyrus, a hunted migratory species with a multinational 
Prajapati et al.: Habitat and Behavioral Observation of Indian Flying Fox ........

home-range and a need for regional management. Journal of Applied Ecology 46: 991-1002.

KOJU, N; CHALISE, M K (2010) Diurnal observation of population and general behaviour of Flying fox (Pteropus giganteus) in Sallaghari, Bhaktapur, Nepal. Journal of Natural History Museum 25: 256-265.

KRYŠTUFEK, B (2005) Distributional status of Indian flying fox Pteropus giganteus in Sri Lanka. Acta Chiropterologica 7: 174-178.

LAMMERTINK, M; NIJMAN, V; SETIORINI U (2003) Population size, Red List status and conservation of the Natuna leaf monkey Presbytis natunae endemic to the island of Bunguran, Indonesia. Oryx 37: 472-479. doi: 10.1017/ S003060530300084X

LIMBU, P; THAPA, K (2011) Chepang Food Culture: Contribution to Wild Edible and Neglected Plant Species. Local Initiatives for Biodiversity Research and Development, LIBIRD, Pokhara, Nepal.

MANANDHAR, S (2015) Population status and daytime behaviour of the Indian flying fox Pteropus giganteus (Brunnich, 1782: Pteropodidae) in Kathmandu valley.

MATHUR, V; PRIYA, Y S; KUMAR, H; ELANGOVAN, V (2012) Reproductive Behaviour and Population Dynamics of Indian Flying fox (Pteropus giganteus). Journal of Threatened Taxa 4(7): 2699-2704.

MOLUR, S; MARIMUTHU, G; SRINIVASULU, C; MISTRY, S; HUTSON, A M; BATES, P J J;WALKER, S; PADMAPRIYA, K; BINUPRIYA, A R (2002) Status of South Asian Chiroptera: Conservation Assessment and Management Plan (C.A.M.P.) Workshop Report. Zoo Outreach Organization/CBSG-South Asia, Coimbatore, India. 
MOLUR, S; SRINIVASULU, C; BATES, P; FRANCIS, C (2008)

Pteropus giganteus. The IUCN Red List of Threatened Species 2008:

e.T18725A8511108.

NYHAGEN, D F; TURNBULL, S D; OLESEN, J M; JONES, C G (2005) An investigation into the role of the Mauritian flying fox, Pteropus niger, in forest regeneration. Biological Conservation 122: 491-497.

O'BRIEN, J (2011) Bats of the western Indian Ocean islands. Animals 1(3): 259-290.

PALMER, C; WOINARSKI, JCZ (1999) Seasonal roosts and foraging movements of the black flying-fox (Pteropus alecto) in the Northern Territory: resource tracking in a landscape mozaic. Wildlife Research 26: 823-838.

RAJCHAL, R (2006) An Overview of the Bats in Sallaghari, Bhaktapur. Bat Net CCINSANewsletter 7: 37.

RAJCHAL, R (2007) Bats of Nepal.Institute of Forestry, Pokhara, Nepal.

REGINALD, J L; PRASATH, PM; MAHENDRAN, C; VENKATASAN, A; PRABHU, K; RAVICHANDRAN, B; MOLUS, S (2008) A survey on the roosting sites of Indian Flying fox Pteropus giganteus Brunnich, 1782 in and around Coimbatore and Palakkad districts, India. Bat Net - CCINSA Newsletter 9: 11-12.

SENTHIKUMAR, K; MARIMUTHU, G (2012) Tree Roosting Fruit Bats (Chiroptera: Pteropodidae) in Southern Tamil Nadu. International Journal of Applied BioResearch 14: 4-10.

SHILTON, LA; ALTRINGHAM, J D; COMPTON, S G; WHITTAKER, V (1999) Old World fruit bats can be long-distance seed dispersers through extended retention of viable seeds in the gut. Proceedings of Royal Society of London 266: 219-223.

SMITH, A T; XIE, Y (2008) A Guide to the Mammals of China. Princeton University Press, Princeton, New Jersey. 
94 Prajapati et al.: Habitat and Behavioral Observation of Indian Flying Fox ........

THAPA, S; DAHAL, D R; POKHREL, S (2012) People Perception of Bats in Sagarmatha (Everest) Zone, Eastern Nepal. Third Seminar on Small Mammals Conservation Issues pp. 14-20.

TIDEMANN, C R; NELSON, J (2004) Long-distance movements of the grey-headed flying fox (Pteropus poliocephalus). Journal of Zoology 263: 141-146.

TIMILSINA, N; GHIMIRE, R (2010) Monitoring of Ptero-camp at LainchaurKathmandu. Small Mammal Mail - Bi-Annual Newsletter of CCINSA \& RISCINSA 2. 24pp

VARDON, M J; BROCKLEHURST, P S; WOINARSKI, J C Z; CUNNINGHAM, R B; DONNELLY, C F; TIDEMANN, C R (2001) Seasonal habitat uses by flying-foxes, Pteropus alecto and P. scapulatus (Megachiroptera), in monsoonal Australia. Journal of Zoological Society of London253: 523-535.

WILLIAMS, N S G; MCDONNELL, M J; PHELAN, G K; KEIM, L D; VAN DER REE, R (2006) Range expansion due to urbanization: Increased food resources attract Grey headed Flying-foxes (Pteropus poliocephalus) to Melbourne. Australian Ecology 31: 190-198.Sitatet dem volorum veles expelent es eum quasper ferunt labore ne molum est, aut dusam et eos modic tecuptat eicaborunt atem qui dolores ipsam, veliquidus sus rem escit quae odi conseque illiam quat.

Agnatquatio. Harionsero iur, idellautaque volecta eptatio omnis sequas doluptatatur a dolectatet ditae lania nust fugit alit alitibus aturescitiam ute nias el il inimiliquae sa pellam, asit lacillu ptatecus niet molor seditat iuntis ut optatii scidunt, aut adipsae vel iliquaturit, volorectur senimusapid mos volupta tibustiur sum fugitem poreriorum aborum et vent occus eos etur sa cor repel invenem lant.

Sediam quiaerc hicillaut dolupiciamus adit que laut que pro inciis alicium utectur sum que vellut eum endit verferia autem voluptate corion non peror sunt, odis magnis volumque pera doloruptat ipsust que optatas imodis int exped qui doluptatis reperumquam rese ni imolorectis nis non reptiunto tecti vendam, ut vendiciaUpta 